\title{
Reflections on Strengthening Ideological and Political Work of University Teachers in the New Age
}

\author{
Haitao Shen, Bo Ran
}

East China University of Science and Technology, Shanghai, China, 200237

Keywords: University Teachers; Ideological and Political Work, Colleges and Universities.

\begin{abstract}
Constructing a team of college teachers with "high ethical and professional ability" is the point of ideological and political work in colleges and universities in the new era. The author thinks that the current ideological and political work in colleges and universities needs to answer the following three questions: What is the relationship between running a socialist university with Chinese characteristics and building a world-class university; How to uphold the party's leadership over higher education and universities; How to do teacher's ideological and political work well. The author tries to take the core content of the speech of general secretary Xi Jinping at the ideological and political work conference in China, combine the spirit of Xi Jinping's series of speeches, puts forward some thoughts on how to strengthen the ideological and political work of university teachers in the new situation.
\end{abstract}

\section{Introduction}

The report of the 19th National Congress of the CPC pointed out: "Give priority to the development of education, and fully implement the Party's education policy and implement the fundamental mission of the Lideshu people." Chinese higher education shoulders the major task of fostering the builders and successors of socialism with an all-round moral, intellectual and physical development. In the decisive stage of building a well-off society in an all-round way and the crucial period for socialism with Chinese characteristics to enter a new era, colleges and universities that run socialism with Chinese characteristics must meet the development direction and road of development and so on, must combine the teaching and research work and ideological and political work in colleges and universities and ensure the common progress of both to ensure the smooth development of higher education in our country development".

\section{The Importance to Strengthen Ideological and Political Work of University Teachers in the New Era}

Strengthening the ideological and political work of university teachers is a key task for further studying and implementing the spirit of the 19th CPC National Congress, the socialist ideology with Chinese characteristics and the ideological and political work sessions of the national higher learning institutions in the new era of Xi Jinping. With the implementation of the State Council's "Overall Plan to Promote World-class Universities and First-class Disciplines as a Whole", colleges and universities will carry out a new round of reform in personnel training mechanisms. Improving the overall quality of university teachers, especially their ideological and political qualities, increasing the intensity of "selecting professionals" and paying more attention to the "educating people" are the strategic needs to further promote Chinese "double-top-class" construction as well as the increasingly fierce domestic and international competition, Unswervingly do a good job with a strong guarantee of the socialist universities with Chinese characteristics [1].

Teachers are the most important factor that affects ideological and political work in colleges and universities to students and is the most direct factor that affects students' political and ideological conditions. Colleges and universities are important positions for knowledge innovation and advanced cultural transmission. It means that college teachers not only undertake the task of imparting professional knowledge, but also take the heavy responsibility of students' ideological 
and political education. This requires that university teachers have a solid theoretical foundation of politics and higher thoughts awareness level. The so-called "planted what seedlings knot what fruit, what seed to open what flowers", the teacher's ideological and quality standards will develop what kind of students. At present, most colleges and universities take "Lide tree people, train students" as the basis, carry out the corresponding ideological and political work for teachers, which not only helps the teachers' political literacy and theoretical level improvement, but also can create a positive environment on campus.

\section{The Ideological and Political Problems Existing in Some College Teachers in the New Situation}

Today, with the increasingly diversified social trend of thought, with the increasing influence of "Internet +", pluralistic values and various ideologies are influencing and impacting on the world outlook, values and outlook on life of college teachers anytime, anywhere, resulting in some problems:

\subsection{Some college teachers re-teaching, light ideological education}

Some research shows that in recent years, college teachers' demands on their own qualifications, university culture and university spirit, as well as their concern for the quality of students, have continued to decline. Many minority teachers have weak political and cultural education. In Shanghai Municipality, the Party Committee for Teaching and Fighting Work started the rolling investigation on the ideological and political conditions of teachers in Shanghai universities in March 2016. In the selection of "teachers 'opinions on the important factors that affect the development of colleges and universities", "teachers' Overall quality "option since 2012, four consecutive decline. "College Culture and University Spirit" has become the "median" of various influencing factors, and the option of "student quality and student quality" is the lowest for five consecutive years [2]. Teachers' concerns are less and less on their own and the ideological and moral cultivation of students and other aspects, we can see that the dominant position of ideological and political work in the work system of colleges and universities have shifted, so that political and ideological work cannot be played " Educate people "subjective initiative.

\subsection{Some teachers have a firm career goal, but their ideals and political acceptance tend to be weaker}

Most of the teachers in colleges and universities have a high degree of concern and recognition for the major policies promulgated by the party and the state and show a high sense of social responsibility and historic mission. However, some teachers regard the teacher's profession as a way of making a living without Aware of the high school teachers in higher education Neolithic people cultivate the successor of the socialist successor mission in the important task. To a certain extent, this shows that teachers' ideals and beliefs in colleges and universities have weakened. The major theoretical viewpoints of Shanghai university teachers on the party and the state show a clear "W" type of fluctuation during the six years from 2010 to 2015, in which "insisting on the guiding position of Marxism in the ideological field of our country" Approval rate continued to decline since 2012, in 2015 there was a significant improvement. The rest of the theoretical points of view are in the trough of 2011 after the increase and change. This is with the gradual progress of the internationalization of university teachers in our country. The opportunities for teachers to go abroad to study for degrees and to exchange ideas and seminars have increased, which is not only affected by the changes in the West and various ideological trends.

\subsection{Some teachers are difficult to resist the impact of market-oriented economic trends, ethics cannot be optimistic}

With the perfection and development of the market economy system, the principle of profit-seeking in the market economy gradually affects the traditional values of colleges and universities. It is naturally difficult for university faculty to avoid being influenced by this view. 
Under the negative influence of some of the college teachers' self-awareness and belief, they have even caused them to pay more attention to the development of self-interest and ignore the improvement of their own ideological and political accomplishments. Some college teachers in the teaching process, simply think that the knowledge of textbooks can point out, for sleeping in class, playing cell phones and other acts of omission, but attributed the responsibility to the students themselves, ignoring their own responsibilities. What is more, the unscrupulous measures taken to achieve the goal, the plagiarism of the theses, the number of academic fraud, and so on, neglecting the academic ethics and professional ethics of the teachers should lead to extremely adverse social impacts [3].

\section{Cause Analysis of Ideological and Political Work Problem of Teachers in Colleges and Universities in the New Era}

There are two main reasons for the above phenomenon, one is personal factors, some teachers in colleges and universities ideological and political consciousness is weak; more is at the institutional level, the current ideological and political work mechanism in colleges and universities is not perfect, improper working methods, not in place.

\subsection{The comprehensive reform of higher education has increasingly entered the deep water area}

In recent years, the number of enrolled students in colleges and universities in our country has been rapidly expanding. The number of students enrolled in colleges and universities has risen sharply and the total amount of teaching work has increased. As a result, teachers have overloaded their teaching tasks and relaxed their ideological and political education and their education to a certain extent. In the meantime, in the new round of "double-top" construction of higher education institutions in our country, competition mechanisms have been introduced one after another, universally adopting management methods such as job title competition, punishment at the last place, non-promotion or non-employment to enhance their sustainable competitiveness, resulting in university teachers facing scientific research Heavy tasks, teaching pressure, job title assessment difficulties and many other issues, increasing the work pressure of college teachers. On the contrary, colleges and universities are not concerned with improving teachers' service mechanism, failing to establish a democratic and smooth communication channel, and avoiding the contradiction between teachers and schools and work.

\subsection{Imperfect work mechanism construction and relatively obsolete work methods}

The mechanism of ideological and political education in colleges and universities is not perfect, and there are few innovations in working methods. At present, most teachers in colleges and universities still lack the system and work less in overall coordination. First of all, there is a lack of a vertical system that specializes in teachers' ideological and political work. There is also a lack of corresponding operational systems and organizational structures and a strong and effective working network. Second, there is not enough innovation in the carriers and methods of carrying out work. The singleness of ideological education, the pertinence of education, and the lack of actual effectiveness have caused the situation that the effectiveness of ideological and political work is not strong.

\subsection{The form of work implement is more than the content, there layers of weakening}

In recent years, the ideological and political work of college teachers has received great attention from the Party and the state. In order to make the related work proceed smoothly, the state has promulgated a series of policy documents such as "Opinions on Strengthening the Construction of Teaching Staff"," Several Opinions on Ideological and Political Work of Young Teachers in Colleges and Universities and Opinions on Strengthening the Construction of Young Faculty Teams in Colleges and Universities. The policy support, platform construction and normative principles have given great protection to the ideological and political work of university teachers. However, in 
the process of actual implementation, the ideological and political work often falls into the category of form and content. The leaders of colleges and universities talked about the meeting or document transmission. However, they did not follow up in actual work. They mostly confined themselves to publicity and formality and were hard to obtain University teachers' approval and support.

\subsection{The assessment system of teachers in colleges and universities focus on the task of teaching assessment of light thinking inspected}

At present, most universities and colleges have initially established a system of teachers' ideological and political work. However, there are still some omissions in the management institutions and evaluation mechanisms. In the training and assessment of teachers, there is a situation where the emphasis on teaching and research and the ideological and political quality are neglected. Some college teachers think that ideological and political work is "retreat" and treated it negatively as a "soft task". They think it is better to focus on teaching and research instead of doing ideological and political work. Or think that ideological and political work theory is too strong and it is difficult to obtain practical results, as its existence. Therefore, the requirements for the ideological and political qualifications of teachers in colleges and universities have always been rather vague. The assessment of ideological and political qualities has also become a formality [4].

\subsection{Feedback between schools and teachers less and poor communication}

At present, the relevant institutions and mechanisms concerning teachers 'ideological and political work in colleges and universities often focus on the standardization and control of teachers' ideological work, neglecting considerations on service, cooperation and consultation. Scientific and rational system and mechanism should include both norms and services. The former refers to the management measures and provisions promulgated by colleges and universities, including management and routine work such as common pre-service training, reports on situations and policies, and work systems for key ideological targets; the latter refers to the work on ideological and political work Of the management and research object service work, that is, in the actual ideological and political work to college teachers to help and service, listening to some teachers' opinions and suggestions, work together to form a benign interaction, and do a good job in college ideological and political education of teacher groups .

\section{The proposals of current college teachers ideological and political work}

To strengthen and improve the ideological and political work of university teachers is an important work carried out by the General Secretary Xi Jinping's series of speeches and the ideological and political work conference of the national higher learning institutions and the implementation of the special inspection tour of the Central Government. So, how to build a world-class university on the basis of socialism with Chinese characteristics and do a good job in ideological and political work of teachers on the basis of the party's leadership over higher education and colleges and universities. The author believes that colleges and universities should establish a system of service to teachers in thinking of political work Vertical cross system, to achieve the following "five comprehensive."

\subsection{College teachers ideological and political work to achieve "full coverage"}

Compared to the past, college teachers not only have a drastic increase in the overall number of people, but also have a complicated composition of personnel. Among the front-line teachers who undertake the main tasks, there are both parties members and teachers, as well as the masses and non-party people, as well as an increasing number of foreign teachers, teachers from Hong Kong, Macao, Taiwan and overseas Chinese; more than first-line teachers, they are mainly employed in administration, management and logistics Staff in different positions. Due to the difference between disciplines and jobs, different teachers have different degrees of receiving ideological and political education. Therefore, in the process of implementing ideological and political work, we should adopt different ways of thinking and political work for teachers of different backgrounds, positions 
and work types so as to achieve "full coverage" and avoid "one size fits all." Regularly organize and take advantage of the life of the joint organization to lead teachers of different posts to learn about the party's policy guidelines and influential major events at home and abroad, strengthen communication and exchange, help teachers to raise their level of ideological understanding, and enhance their discrimination with "full coverage" And ability to resist wrong thoughts.

\subsection{Ideological and political education should be run through the "whole process" of university teacher management}

Ideological and political education cannot be a working system of individual modules. It should be integrated into ideological and political work throughout the entire process of school education and teaching, scientific research, social services, cultural heritage and innovation, and international exchanges and cooperation. In teaching, on the one hand pay attention to some teachers, "make up classes", especially in colleges and universities to undertake more teaching less involved in ideological and political education science and engineering subjects teachers; second is to resist the "emphasis on scientific research teaching" atmosphere, Pay Attention to Teachers' Assessment of Ideological and Political Accomplishment. In scientific research, we must resolutely boycott academic misconduct and continuously improve teachers' ability to think and practice so that they will establish a professional spirit of dedication, pragmatism and enterprising. Teachers should be encouraged to participate in social practice and help teachers understand the national conditions and feelings of the people and deepen their understanding of the party's basic principles and policies through investigation and study, study tours and volunteer services. When participating in international exchanges, colleges and universities should pay close attention to new trends in the field of ideology, grasp the teacher's ideological trends in real time, and establish a comprehensive collection, analysis and reporting mechanism of public opinion among teachers, so as to enhance the timeliness and effectiveness of ideological work.

\subsection{The ideological and political work connect teachers' career "full cycle"}

In the teachers' induction, induction, promotion, transfer, until after retirement, must be targeted to strengthen education and guidance, the ideological and political work throughout the entire life cycle of the professional development of teachers. For newly recruited young teachers, young teachers' teaching ability and ideological and political qualities can be improved through pre-service training and old belt matchmaking. According to the teacher's own interests, personality and other aspects, the teacher's future development to make a reasonable positioning, and determine the appropriate career goals, to help teachers in different stages of planning in advance to ease the work, family and other external pressure. In the transfer of teachers assessment, job title appraisal, evaluation priority work, we should take the ideological and political performance as an important criterion, teachers and ethics firmly implement the "one-vote veto system", so "full cycle" to strengthen the teacher's thinking Political, professional ethics, academic standards and other requirements.

\subsection{Carry out teacher ideological and political work to achieve "all-round"}

Ideological and political education in colleges and universities should adhere to the combination of solving the ideological problems and solving practical problems, and carry out all-round teacher ideological and political work from the teachers' ideological education, business development and living families. On the one hand, ideological and political work in colleges and universities should give full play to organizational advantages, on the one hand, promote the improvement of teaching abilities and academic research capabilities, and actively promote the education of experienced teachers and young teachers in twinning. Through "twinning" and "mentoring" Effectively improve the teaching level of young teachers; at the same time, pay attention to guiding career planning of college teachers, and promote the professional planning ability of college teachers, especially young teachers, from the aspects of science, rationality and feasibility; on the other hand, colleges and universities should base themselves on In fact, practical measures should be taken to help young teachers solve problems in their daily life, work and development, such as teacher medical care, 
housing and child enrollment, so that they can engage in teaching and research with peace of mind and devote more time to Self-improvement and thinking of educating people [5].

\subsection{Implement the teacher's ideological and political work to achieve "all measures"}

To improve the teacher education and evaluation mechanism, the performance of outstanding teachers, to focus on training, recognition awards; poor performance of teachers, timely exhortations, supervision and rectification; We should strengthen the ideological and political education in school network platform construction, through the evaluation of teachers' morality by students and colleagues, the use of new media carriers to enhance the mainstream opinion of the network of public opinion positions. Increase penalties for academic exaggeration, academic misconduct, academic corruption and other issues, and strengthen teachers' ideological and political, professional ethics, academic standards and other requirements. Colleges and universities should make use of and strengthen various means of rewards and punishments to expand the influence of public opinion and "all measures" to enhance teachers' ideological and political level and their professional ethics [6].

In a word, building a contingent of college teachers with "high academic excellence" is the key point of ideological and political work in colleges and universities under the new normal. We must fully recognize the necessity of doing a good job in the ideological and political work of teachers, strengthen the cultivation of teachers 'professionalism, and at the same time, strengthen the education of teachers' ideal and faith. Guide teachers to firmly establish the core values of socialism, encourage and require the majority of teachers to adhere to the unity of teaching and educating people, words and deeds are unified, with great concentration and attention to social unification; strengthen the teachers' laws and regulations, ethics, Basic norms of training, to promote the majority of teachers in order to act virtue, morality and moral education, construction of socialism with Chinese characteristics world-class university.

\section{References}

[1] DI Yan-ru. Colleges and universities to promote young teachers ideological and political work of the strategic thinking [J]. Ideological and theoretical education, 2013, (04): 129-131.

[2] Zhang Er-Yan, Chang-Jie. Under the new situation on strengthening the ideological and political work of young teachers in colleges and universities thinking [J]. State Forestry Administration Journal of Management Cadres, 2015, 14 (03): 22-25.

[3] Song Fanmeng, Xu Yuqian. The Evolution and Optimization of Ideological and Political Work of Young Teachers in Colleges and Universities [J]. Journal of the National Academy of Education, 2015, (03): 44-49.

[4] He Xianglin, Wu Changjin. Current situation and countermeasures of ideological and political work among young teachers in colleges and universities - An empirical research based on six colleges and universities [J]. Ideological Education Research, 2016, (01): 116-119.

[5] Jiling. Problems and countermeasures in the current ideological work of young teachers in colleges and universities [J]. Jiangsu Higher Education, 2016, (01): 85-87.

[6] Chen Lisi. Reflections on Several Issues in Current Ideological and Political Work in Colleges and Universities [J]. Chinese Youth Social Science, 2017, 36 (03): 8-16. 